\title{
Water-Yield Relationships in Deficit Irrigated Cabbage
}

\author{
Serhat AYAS1* \\ Yenisehir İbrahim Orhan College, University of Uludag, Yenisehir, Bursa, Turkey. \\ *Corresponding author e-mail: serayas@uludag.edu.tr
}

\begin{abstract}
This trial was realized in Yenisehir Vocational School between 2007 and 2008 on the purpose of study out the influence of lack of water in four growth periods of cabbage. In this trial, fourteen irrigation treatments was formed considering the growth periods (establishment, vegetative, yield formation and ripening) of cabbage (Brassicaceae Oleracea var. capitata L. Grandslam F1) and the results obtained from these treatments were evaluated. According to the content of the treatments, the water amount to the plants varied between 0 and $524 \mathrm{~mm}$ in the 2007 year, and between 0 and $536 \mathrm{~mm}$ in the 2008 year. Water consumption of cabbage in the 2007 year ranged between 200 and $795 \mathrm{~mm}$ and in the 2008 year ranged between 190 and $802 \mathrm{~mm}$. Yield, head weight, diameter, height and dry matter ratio were determined statistically important. In 2007 and 2008 years, the maximal yield were found as $74.2 \mathrm{tha}^{-1}$ and $72.4 \mathrm{tha}^{-1}$ in the $\mathrm{E}_{100} \mathrm{~V}_{100} \mathrm{Y}_{100} \mathrm{R}_{100}$ treatments, while the minimal yield were found as $2.0 \mathrm{t} \mathrm{ha}^{-1}$ and $4.0 \mathrm{ha}^{-}$ ${ }^{1}$ in the $\mathrm{E}_{0} \mathrm{~V}_{0} \mathrm{Y}_{0} \mathrm{R}_{0}$ treatments, respectively. Water- yield relationship factor $\left(\mathrm{k}_{\mathrm{y}}\right)$ in 2007 and 2008 years were found as 0.96 and 0.97 , respectively.
\end{abstract}

Key words: Cabbage, deficit irrigation, WUE and IWUE values, yield and quality parameters of cabbage, irrigation planning. 


\section{Introduction}

Van Straten et al., (2010) stated that the greenhousing is worldwide the fastest growing sector of all agricultural production activities. There are two essential causes for this. First, the plant grows in greenhouse differently from the external environment, in this way supplying some way of abri from the direct effect of the external environment. This allows the production of crops at that specific place. Second, the greenhouse allows to be produced of many crops. This situation permits the grower to direct the farming in a preferable aspect. It causes to more crop yield, extended production period, less use of chemicals, better quality. The value added per decare in greenhouse crops is much more than that in field agriculture.

The world's the biggest cabbage producers are China, India and Russia with 33400000,9000 000 and 3500000 tons, respectively (FAOSTAT, 2014). Russia is the largest cabbage consuming country. Turkey is one of the significant cabbage producer with 785791 tons in the world (FAOSTAT, 2016). The cabbage is considered to be of European origin and grows along the North Sea, the English Channel and Northern Mediterranean. Lahana is prefered because of its various advantages such as the growth of the various climate and soil conditions, its easy of production and storage and its high food value. The cabbage is eaten up as cuisine dish in our country along with salad, raw, wrap and pickle (Vural et al., 2000). Sezen, (2005) found that surface irrigation doesn't suggest because of the low of irrigation efficiency result from drainage and salinity in plantations. Irrigation with less amount of water is important such as sprinkler and drip irrigations. There is a need for more efficient irrigation systems support to improve agricultural targets and irrigation efficiency. Moreover, irrigation water by drip irrigation is used more effective and over-irrigation causes yield losses. Thus, irrigation method is really crucial with regard to irrigation planning (Anonymous, 2005).

Irrigation planning aims of the soil water deficit to not falling below the critical level for a specific soil and crop condition. This may enable to avoid the harmful effect of water stress by means of estimating the earliest date (Ritchie and Johnson, 1990). Irrigation water is used effectively thanks to drip irrigation system. Extreme irrigation lowers yield, while insufficient irrigation reduces production and brings about water stress.

Irrigation planning with drip irrigation relies on approaches related to evapotranspiration estimations (Bar-Yosef and Sagiv, 1982; McNeeish et al., 1985; Clough et al., 1990; Hartz, 1993) and permissible soil-water consumption (Bogle et al., 1989). $K$ values usually difficult to create accurately. Because regional conditions, soil properties, crop physiology and cultural practices affects to $K$ values. A suggested $K$ value for irrigation planning must be high enough to avoid the water stress caused by the needs and specific local situations. It remains low enough for effictive water management (Yuan et al., 2003)

Some studies have been made to research the effect of deficit irrigation on cabbage. The purposes of this trial were to obtain a prospectus for cabbage growers and to determine drip irrigated cabbage response to deficit irrigation modes in Bursa conditions. As a result, drip irrigation method preferred in the study.

\section{Material and Methods}

The trial was realized in Yenisehir Vocational School, Bursa in 2007 and 2008 years. For practical purposes, plastic greenhouse $(8 \mathrm{~m} \mathrm{x} 40 \mathrm{~m})$ was used. In the study place, winters 
are cold and summers are hot. The average annual rainfall and temperature values for the region where the greenhouse experiments were made in 2007 and 2008 were 482,9-630,7 mm and $13,6-12,9{ }^{\circ} \mathrm{C}$ respectively. While the average minimum temperature for 2007 and 2008 were $6,6-(-5,9){ }^{\circ} \mathrm{C}$ between January and December, the average maximum temperature in August was measured as 32,9 and $34,6^{\circ} \mathrm{C}$ (Anonymous, 2010). The soil of study place was sandy clay and $\mathrm{pH}$ value of soil ranged between 7.86 and 8.05. The specific features of the soil are given in Table 1.

A suitable well for irrigation was used as the water source in the trial area and the quality of irrigation water was determined as $\mathrm{C}_{1} \mathrm{~S}_{1}$. $3 \times 15$ NPK manure was utilized to trial plots while the cabbages were being planted, and $75 \mathrm{~kg}$ of $3 \times 15$ NPK manure per decares were utilized. The urea form of the nitrogen was applied to the plots together with water. $25 \mathrm{~kg}$ manure (\% $46 \mathrm{~N}$ ) per decare in vegetative period was applied as the first manure application, while $25 \mathrm{~kg}$ manure $(\% 46 \mathrm{~N})$ per decare was applied along with irrigation water during the yield formation period. Furthermore, during the vegetative and yield formation periods the generative growth of plant was supported by using $25 \mathrm{~kg}$ of magnesium nitrate manure per decares $(11-0-0+$ $16 \mathrm{MgO}$ - Nitrogen \% 11 and $\mathrm{MgO} \% 16$ ). The cabbage seedlings were transplanted into the trial pots on August 03, 2007 and on August 012008 years, respectively. Seedlings were planted on the same line and at a distance of $60 \mathrm{~cm}$ between the plant lines. The specific parameters of cabbage are yield, head weight, diameter, height and dry matter ratio. The four heads harvested from the middle of the plots were weighed and head weight were determined by the averages of these values. Head diameter and height were calculated by measuring with a scale/ruler. The dry matter ratio of the cabbage was calculated by drying the leaves of the fruit in a drying oven for 48 hours and at $65^{\circ} \mathrm{C}$. The trial design was formed by randomly distributing fourteen different treatments on three different blocks. The size of trial plots was $4 \mathrm{~m}^{2}(2.0 \mathrm{~m} \times 2.0 \mathrm{~m})$ and the intervals between blocks and plots were $2.0 \mathrm{~m}$ and $0.75 \mathrm{~m}$, respectively. Each plot had 9 plants and $0.60 \mathrm{~m}$ apart between the rows with $0.60 \mathrm{~m}$ spacing in each row. The detail of one of the trial plot is shown in Figure 1.

In growth periods of the cabbage (establish, vegetative, yield formation and ripening) were formed fourteen deficit irrigation treatments based on full or deficit irrigation applications, $0.75-50-0.25 \%$ of the deficit irrigations were applied in different growth periods of the plant (establishment, vegetative, yield formation and ripening), while in the fully irrigated treatments, all of this water was applied. In line with this planning, irrigation treatments were planned like this: $\mathrm{E}_{100} \mathrm{~V}_{100} \mathrm{Y}_{100} \mathrm{R}_{100}, \mathrm{E}_{75} \mathrm{VYR}, \mathrm{E}_{50} \mathrm{VYR}_{\mathrm{R}} \mathrm{E}_{25} \mathrm{VYR}, \mathrm{EV}_{75} \mathrm{YR}, \mathrm{EV}_{50} \mathrm{YR}, \mathrm{EV}_{25} \mathrm{YR}, \mathrm{EVY}_{75} \mathrm{R}$, $\mathrm{EVY}_{50} \mathrm{R}, \mathrm{EVY}_{25} \mathrm{R}, \mathrm{EVYR}_{75}, \mathrm{EVYR}_{50}, \mathrm{EVYR}_{25}, \mathrm{E}_{0} \mathrm{~V}_{0} \mathrm{Y}_{0} \mathrm{R}_{0}$ (Table 2.).

In the trial, the plants were irrigated drip irrigation method and water was provided from an irrigation well. The specific features of the irrigation water utilized in the study are given in Table 3. The water has low-sodium risk, has a medium EC and is in $\mathrm{C}_{2} \mathrm{~S}_{1}$ class. In growth periods of plant, the damp contains of the soil was followed before and after irrigation with a gravimetric method in every $30 \mathrm{~cm}$ till $120 \mathrm{~cm}$ depth.

ET, was calculated by means of water balance equation (Eq. 1) ${ }^{11}$.

$\mathrm{ET}=\mathrm{I}+\mathrm{P}-\mathrm{R}_{\mathrm{f}}-\mathrm{D}_{\mathrm{p}} \pm \Delta \mathrm{S}$ 
Where, ET represents the evapotranspiration, I shows the irrigation water $(\mathrm{mm}), \mathrm{P}$ is the precipitation, $R_{f}$ is the surface flow $(\mathrm{mm}), D_{p}$ is deep drainage $(\mathrm{mm})$ and $\Delta S$ is the between two soil water changing in effective root depth $(\mathrm{mm} / 90 \mathrm{~cm})$. Before planting seedlings, water was used to the tomato with the drip irrigation method. Total precipitation $(\mathrm{P})$ and surface flow $\left(\mathrm{R}_{\mathrm{f}}\right)$ was omitted and the soil moisture between the depths of 90 to $120 \mathrm{~cm}$ of the soil is accepted as the deep drainage $\left(D_{p}\right)$. However, during the growing period, soil moisture changes between 90 and $120 \mathrm{~cm}$ were not followed and the deep drainage was accepted as " 0 ". In this trial, the relationships between yield and ET is defined by the Steward Model (Eq.2) (Stewart et al., 1975; Doorenbos and Kassam, 1979). The equation can be showed as

$$
\left(1-\frac{Y a}{Y m}\right)=k y\left(1-\frac{E T a}{E T m}\right)
$$

Where $Y_{m}(t / h a)$ and $Y_{a}(t / h a)$ are maximal and real yield, respectively, $\mathrm{ET}_{\mathrm{m}}(\mathrm{mm})$ and $\mathrm{ET}_{\mathrm{a}}(\mathrm{mm})$ are maximal and real evapotranspiration, respectively. The yield response factor is shown as $\mathrm{k}_{\mathrm{y}}$. WUE values were determined to assess irrigation efficiency in treatments. WUE and IWUE terms refer to contribution of irrigation water to effective use of plant production stages (Bos, 1980). The ratio of yield (YLD) to $\mathrm{ET}_{\mathrm{a}}$ expressed as WUE and it is demonstrated as $\mathrm{WUE}=\mathrm{YLD} / \mathrm{ET}_{\mathrm{a}}\left(\mathrm{kg} / \mathrm{m}^{3}\right)$. IWUE was predicted by the following equation;

$$
\operatorname{IWUE}\left(\text { tha }^{-1}\right)=\frac{Y L D-Y L D_{\text {rainf ed }}}{I R G A}
$$

Where YLD is yield and YLD rainfed is the yield found from the rainfed treatment, IRGA is the seasonal water amount $(\mathrm{mm})$. The damp content of the soil till $90 \mathrm{~cm}$ depth was calculated before the seedlings were planted into the soil. All treatments were completed in the level of field capacity. In 2007 year, irrigation was started on August 10, 2007 and in 2008 year was started on August 08 and irrigation was done every 7 days. The irrigation water for the four growth stages are given in Table 4. Crop evapotranspiration for the different growth stages are given in Table 5.

Product efficiency and quality parameters are evaluated. Variance analysis was done with the values of product productivity and productivity components by using MSTAT-C and MINITAB software (Steel and Torrie, 1980).

\section{Results}

In 2007 and 2008 years, maximal irrigation water was found in $E_{100} V_{100} Y_{100} R_{100}$ treatment as $524-536 \mathrm{~mm}$ and minimal irrigation water was found in $\mathrm{E}_{0} \mathrm{~V}_{0} \mathrm{Y}_{0} \mathrm{R}_{0}$ treatment as $0-0 \mathrm{~mm}$, respectively. Plant water consumption of the cabbage $\left(\mathrm{ET}_{\mathrm{c}}\right)$ went up with the increment in the water amount. In $\mathrm{E}_{100} \mathrm{~V}_{100} \mathrm{Y}_{100} \mathrm{R}_{100}$ and $\mathrm{E}_{0} \mathrm{~V}_{0} \mathrm{Y}_{0} \mathrm{R}_{0}$ treatments, it was found as 200-795 $\mathrm{mm}$ in 2007 year and as $190-802 \mathrm{~mm}$ in 2008 year, respectively. The irrigation water and yield values are given in Table 6 .

Linear relationships between $\mathrm{ET}_{\mathrm{c}}$ with $\mathrm{Y}_{\mathrm{a}}$, and IW with $\mathrm{Y}_{\mathrm{a}}$ were observed for 2007 year. The relationship equation is as follows; $Y_{a}=0.1166 E T_{c}-16.57$ with $R^{2}=0.95$ and $Y_{a}=$ $0.1343 I W+2.0828$ with $R^{2}=0.92$ (Fig 2 and Fig 3 ). 
Linear relationships between $\mathrm{ET}_{\mathrm{c}}$ with $\left(\mathrm{Y}_{\mathrm{a}}\right)$, and IW with $\mathrm{Y}_{\mathrm{a}}$ were observed for 2008 year. The relationship equation is as follows; $Y_{a}=0.1343 E T_{c}-2.0828$ with $R^{2}=0.92$ and $Y_{a}=$ $0.1274 I W+3.1626$ with $R^{2}=0.93$ (Fig 3 and Fig 4).

As for that the trial results, irrigation applications considerably influenced the yield

(Fig. 2 and Fig. 3), and when they were assessed as the values of 2007 and 2008, the maximal values of yield were found as $74.2 \mathrm{tha}^{-1}$ and $72.4 \mathrm{tha}^{-1}$ in $\mathrm{E}_{100} \mathrm{~V}_{100} \mathrm{Y}_{100} \mathrm{R}_{100}$ treatment (Table 8 and Table 9).

When $\mathrm{E}_{100} \mathrm{~V}_{100} \mathrm{Y}_{100} \mathrm{R}_{100}$ treatment was made comparison with the other irrigation treatments, yield losses were determined as $0.5 \%, 2.6 \%, 5.0 \%, 8.5 \%, 10.4 \%, 11.2 \%, 16.9 \%$, $18.2 \%, 24.5 \%, 35.4 \%, 41.6 \%, 46.6 \%$ and $3610.0 \%$ in 2007 year and $0.6 \%, 1.4 \%, 2.4 \%, 6.6 \%$, $7.1 \%, 21.7 \%, 13.3 \%, 19.3 \%, 25.0 \%, 25.7 \%, 39.0 \%, 43.7 \%$ and $1710.0 \%$ in 2008 year. In the trial, it was study out that deficit irrigation has an important effect on yield and quality parameters at $\mathrm{P}<0.05$ level.

While a positive straight line relationship was obtained between the water amount and the yield, head weight, diameter, height; a negative straight line relationship was obtained between the irrigation amount and dry matter ratio. As for that the relationship, these results were determined: head weight $(2007)=0.01 \mathrm{IW}+0.3464, \mathrm{R}^{2}=0.96$ and head weight $(2008)=$ $0.0099 \mathrm{IW}+0.271, \mathrm{R}^{2}=0.94$ (Fig. 4.a.); head diameter $(2007)=0.0447 \mathrm{IW}+3.6228, \mathrm{R}^{2}=0.84$ and head diameter $(2008)=0.043+4.8106, R^{2}=0.85$ (Fig. 4.b). Head height $(2007)=0.0399 \mathrm{IW}$ $+4.6067, \mathrm{R}^{2}=0.88$ and head height $(2008)=0.0404 \mathrm{IW}+5.4357, \mathrm{R}^{2}=0.90$ (Fig. 4.c.); dry matter ratio $(2007)=-0.012 \mathrm{IW}+13.876, \mathrm{R}^{2}=0.92$ and dry matter ratio $(2008)=-0.0124+$ 14.072, $\mathrm{R}^{2}=0.90$ (Fig. 4.d.).

\section{Crop yield response factor $\left(k_{y}\right)$}

Crop yield response facto $\left(\mathrm{k}_{\mathrm{y}}\right)$ is defined as the linear relationship between relative crop evapotranspiration and relative yield decrease. This is accepted to be the response of the yield to the relative crop evapotranspiration. In another saying, it indicates the decrease in the yield corresponding to each level of deficit in water consumption. Seasonal crop yield factors (ky) were determined as 0.96 (2007 year) and 0.97 (2008 year) (fig.5). The increase in ky value is due to the increase in the water deficiency. This result shows that the seasonal crop yield factors are a bit low in the period of cabbage but it is accordant with the crop yield factors in the every growth periods given in literature. The difference of results may refer to the differences between the empirical, soil conditions, climatic.

\section{Water use efficiencies}

WUE and IWUE values of the 2007 and 2008 years, when the trial was performed, were obtained different allied to the treatments (Table 10). The maximal WUE values for 2007-2008 years were found as $0.09,0.10,0.10-0.09,0.09,0.10$ and $0.09,0.09,0.10-0.09,0.09,0.09$ $\mathrm{kg} \mathrm{mm}{ }^{-1}$ from E75VYR, E50VFYR, E25VYR and EV75FYR, EV50FYR, EV25FYR treatments, respectively. IWUE values for 2007-2008 years were found as $0.14,0.14,0.14-$ $0.14,0.15,0.16 \mathrm{~kg} \cdot \mathrm{mm}^{-1}$ and $0.14,0.14,0.15-0.14,0.15,0.14 \mathrm{~kg} \mathrm{~kg} \cdot \mathrm{mm}^{-1}$ respectively. When WUE and IWUE values were taken into consideration, the maximal WUE and IWUE values 
were obtained from establishment and vegetative periods and the lowest value was obtained from yield formation and ripening periods. In another saying, the maximal yield was found and the most water was saved with deficit irrigation only in the establishment and early vegetative periods of the cabbage.

\section{Discussion}

In our trial, irrigation treatments considerably influenced yield, head height, diameter, weight and dry matter. Total water amounts range from 380 to $500 \mathrm{~mm}$ subject to the length of growing season and climate (Doorenbos and Kassam, 1979). Kumar and Sahu (2013) reported that the total depth of water for cabbage applied were 107 and $268 \mathrm{~mm}$, respectively. Agrawal et al. (2018) determined that water used for cabbage varied from 189 to $710 \mathrm{~mm}$. Kiziloglu et al. (2007) specified that $449.4 \mathrm{~mm}$ irrigation amount and $932 \mathrm{~mm}$ evaporation were applied to the plants in whole growth period. Wahome et al. (2009) stated that water applied for cabbage varied from 420 to $491 \mathrm{~mm}$ in different treatments and two mulch materials. Sammis and Wu (1989) found that the irrigation amount ranged from 0.42 to $1.94 \mathrm{~mm}$ and plots were arranged in the form of a tree repeated gradient irrigation. Abdel et al. (1994) reported that irrigation water was applied 3.6 and $9 \mathrm{~mm}$ day-1 during the growth period of cabbage (Brassica oleracea var. capitata L.) and irrigation frequencies were preferred 1 and 3 days in winter conditions of Oman in the Gulf region. Smittle et al. (1994) notified that the water applied for cabbage changed from 71 to $182 \mathrm{~mm}$. In the same study, pan evaporation values varied from 131 to $270 \mathrm{~mm}$. Bucks et al. (1973) indicated that the consumptive use requirement (380 $\mathrm{mm}$ of water) for high production of cabbage was about the same for all irrigation methods. Sammis et al. (1988) reported that the plant consumptions of lettuce and Chinese cabbage were $205 \mathrm{~mm}$ and $209 \mathrm{~mm}$, respectively. Kiziloglu et al. (2008) specified that the total evapotranspiration for red cabbage in Turkey conditions was $937 \mathrm{~mm}$. In the first year of the trial, a total of $524 \mathrm{~mm}$ of the amount of irrigation water was applied to the $\mathrm{E}_{100} \mathrm{~V}_{100} \mathrm{Y}_{100} \mathrm{R}_{100}$ treatment which was applied in full water and $536 \mathrm{~mm}$ in the second year. In addition, the plant water consumption of cabbage was determined as 795 and $802 \mathrm{~mm}$ in 2007 and 2008 years for $\mathrm{E}_{100} \mathrm{~V}_{100} \mathrm{Y}_{100} \mathrm{R}_{100}$ treatment. The results of the irrigation amounts and crop water consumption values of the trial were compatible with previous studies (Bucks et al., 1973; Doorenbos and Kassam, 1979; Sammis et al., 1988; Sammis and Wu, 1989; Smittle et al., 1994; Abdel et al., 1994; Kiziloglu et al., 2007; Kiziloglu et al., 2008; Wahome et al., 2009; Kumar and Sahu, 2013; Agrawal et al., 2018).

The cabbage yield for 2007 and 2008 years ranged between 74.2-2.0 and 72.4-4.0 tha${ }^{1}$, respectively. The results of our study shows that the influence of deficit irrigation on yield was quite important. According to the yield results, all treatments were ranked as the different statistical groups. It is concluded that the amount of irrigation water applied to different phenological periods of the plant was important on the yield value of the plant. This result is in agreement with those of (Doorenbos and Kassam, 1979; Nortje and Henrico, 1988; Sammis et al., 1988; Jangandi et al., 2000; Beltrao et al., 2000; Bogoescu, 2000; Imtiyaz et al., 2000; Salo et al., 2002; Tiwari et al., 2003; Wahome et al., 2009; Sturm et al., 2010; Himanshu et al., 2012; Kumar and Sahu, 2013; Xu and Leskovar, 2014; Seciu et al., 2016; Agrawal et al., 2018). 
At all of treatments except for $\mathrm{E}_{100} \mathrm{~V}_{100} \mathrm{Y}_{100} \mathrm{R}_{100}$, yield was significantly lowered as irrigation water amount decreased. As determined in yield, the quality values of the cabbage (head weight, diameter, height and dry matter) have given a similar response to deficit irrigation. As expected, the non-irrigated $\left(\mathrm{E}_{0} \mathrm{~V}_{0} \mathrm{Y}_{0} \mathrm{R}_{0}\right)$ treatment had lower values than all irrigation treatments. Head weight, diameter ve height values were not included in different statistical groups. This situation is that the amount of irrigation water had a good few effect on head weight, diameter and height. However, the amount of irrigation water had no significant effect on head weight, diameter and height. This situation can be attributed to the fact that plant water consumption wasn't high during plant growing period. These values are similar to those of previous studies (Janes, 1950; Wahome et al., 2009; Himanshu et al., 2012; Kushwah and Dwivedi, 2013; Kumar and Sahu, 2013; Xu and Leskovar, 2014; Agrawal et al., 2018). Since all treatments in the trial had lower than $\mathrm{E}_{100} \mathrm{~V}_{100} \mathrm{Y}_{100} \mathrm{R}_{100}$ treatments. The minimal dry matters were found at $\mathrm{E}_{100} \mathrm{~V}_{100} \mathrm{Y}_{100} \mathrm{R}_{100}$ treatments while the minimal dry values were observed at $\mathrm{E}_{0} \mathrm{~V}_{0} \mathrm{Y}_{0} \mathrm{R}_{0}$ treatments in 2007 and 2008 years of the study. We may infer that important increments in dry matter may be provided by the rising level of irrigation water deficiency. The results obtained from the trial are in conformance with those of (Janes, 1950; Abdel et al., 1994; Bogoescu, 2000; Wahome et al., 2009).

The maximal WUE and IWUE values for 2007 and 2008 years found as 0.16-0.15 and $0.15-0.15$, respectively. The maximal WUE and IWUE values were found in establishment and vegetative periods and the lowest value was obtained from yield formation and ripening periods. When the findings of several researchers compared with the results of our study, the findings were found to be same to (Doorenbos and Kassam, 1979; Sammis et al., 1988; Himanshu et al., 2012; Kushwah and Dwivedi, 2013; Agrawal et al., 2018). These values were influenced climate, variety and soil structure. As explained by Davis et al. (2008), it may be attributed to the variety and applied cultural practices handling under different climate and geographical conditions. Crop yield response factor $\left(\mathrm{k}_{\mathrm{y}}\right)$ for 2007 and 2008 year were calculated as 0.96 and 0.97 for cabbage, respectively. The specified values of $\mathrm{k}_{\mathrm{y}}(0.96-0.97)$ which is lesser than 1.00 shows that cabbage is susceptible to the water. Research values who studied on similar issues also matches up with $\mathrm{k}_{\mathrm{y}}$ factor (Doorenbos and Kassam, 1979; Sammis et al., 1988; Himanshu et al., 2012; Kushwah and Dwivedi, 2013; Agrawal et al., 2018).

\section{Results}

According to the results of the study, irrigation water were applied 524 and $536 \mathrm{~mm}$ in $\mathrm{E}_{100} \mathrm{~V}_{100} \mathrm{Y}_{100} \mathrm{R}_{100}$ treatment applied to full irrigation in 2007 and 2008 years. The plant water consumption of cabbage was determined as 795 and $802 \mathrm{~mm}$ in 2007 and 2008 years for $\mathrm{E}_{100} \mathrm{~V}_{100} \mathrm{Y}_{100} \mathrm{R}_{100}$ treatment. Crop yield response factors $\left(\mathrm{k}_{\mathrm{y}}\right)$ for the different plant growth periods (Establishment, vegetative, yield formation and ripening) were found as $0.47,0.84$, $1.23,1.28$ in 2007 year and $0.49,0.88,1.25,1.26$ in 2008 year. Crop yield response factor (ky) for the total growth period was found as 0.96 in 2007 year and as 0.97 in 2008 year. The highest crop yield response factor values were obtained from the ripening and yield formation periods. These values for 2007 and 2008 years were calculated as 1.28-1.23 and 1.26-1.25, respectively. The highest crop yield response factors ( $\mathrm{ky}$ ) obtained from ripening and yield formation periods showed that the cabbage was susceptible to water in these periods. The highest yield decreases in all plant growth periods were in ripening and yield formation, while the lowest yield 
decreases were in establishment and vegetative periods. In our trial, it was studied out that irrigation treatments considerable influences yield, head diameter, weight, height and dry matter ratio. In 2007 and 2008 years, the maximal yield was $73.3 \mathrm{t} \mathrm{h}^{-1}$ and it was found in $\mathrm{E}_{100} \mathrm{~V}_{100} \mathrm{Y}_{100} \mathrm{R}_{100}$ treatment. The minimal yield was found as $3.0 \mathrm{~h}^{-1}$ in $\mathrm{E}_{0} \mathrm{~V}_{0} \mathrm{Y}_{0} \mathrm{R}_{0}$ treatment. The yield decreased significantly due to the irrigation water deficiency. The relative decreases in yield in 2007 and 2008 were $\% 0.5, \% 2.6, \% 5.0, \% 8.5, \% 10.4, \% 11.2, \% 16.9, \% 18.2, \% 24.5$, $\% 35.4, \% 41.6, \% \% 46.6, \% 3610.0$ and \%6.0, \%1.4, \%2.4, \%6.6, \%7.1, \%21.7, \%13.3, \%19.3, $\% 25, \% 25.7, \% 39, \% 43.7, \% 1710$, respectively. WUE and IWUE values of establishment and vegetative periods were the lowest values. In water deficiency conditions, the establishment and vegetative periods of cabbage are the most suitable periods for deficit irrigation and the yield and quality value decreases was the lowest during these periods.

As a result, of a possible deficit irrigation in a semi-humid climate condition, it is necessary to plan carefully and it is possible to say that the levels and times of the deficit irrigation were significantly effective on cabbage yield. In cabbage irrigation, if the deficit irrigation treatment is obligatory, water deficiency should be planned only for establishment and vegetative periods. The water deficiency shouldn't be applied in other plant growth periods and irrigations during ripening period should be exactly applied. In addition, in the irrigation planning to be done in similar climatic conditions may be benefited from crop yield response factor (ky) values. The results used to determine the amount of reduction in yield in response to the water deficiency to be applied to the plant may be used in studies related to cabbage.

\section{References}

Abdel Rahman, H.A., Ibrahim, A.A., Elias, S.A., 1994. Effect of frequency and quantity of irrigation on growth and yield of cabbage (Brassica oleracea L.). European Journal of Agronomy 3(3): 249-252.

Agrawal, N., Tamrakar, S.K., Tripathi, M.P., Tiwari, R.B., 2018. Response of cabbage under different levels of irrigation and fertigation through drip. Int.J.Curr.Microbial.App.Sci. Special Issue (6): 750-759.

Aldrich, R.A, Barto, J.W., 1989. Greenhouse Engineering. NRAES-33, 203 pp.

Anonymous, 2005. The Annual Report of Meteorological Station, Bursa.

Anonymous, 2010. The Annual Report of Meteorological Station, Bursa.

Bar-Yosef, B., Sagiv, B., 1982. Response of tomatoes to $\mathrm{N}$ and water applied via a trickle irrigation system. II Water. Argon. J., 74: 637-639.

Beltrao, J., Faria, J., Miguel, G., Chaves, P., Trindade, D., 2000. Cabbage yield response to salinity of trickle irrigation water. Acta Hort. 537:641-645. DOI: 10.17660 / Acta Hortic. 2000. 537.75. 
Bogle, C.R., Hartz, TK, Nuntoez, C., 1989. Comparison of subsurface trickle and furrow irrigation on plastic mulched and bare soil for tomato production. J. Am. Soc. Hortic. Sci., 114: 40-43.

Bogoescu, M., 2000. The water quality and irrigation method influence about the autumn white cabbage yield. Acta Hort. 533: 447-450. DOI: 10.17660/ActaHortic.2000.533.55.

Bos, M.G., 1980. Irrigation efficiencies at crop production level. ICID Bull.29: 18-25

Bucks, D.A., 1973. Quantity and frequency of trickle and furrow irrigation for efficient cabbage production. Agronomy Journal, Vol.66, No (1): 53-57.

Clough, G.H., Locasio S.J., Olsen S.M., 1990. The yield of successively cropped polyethylene mulched vegetables as affected by irrigation method and fertilization management. J. Am. Soc. Hortic. Sci. 115: 884-887.

Davis, A.R., Webber, C.L., Perkins-Veazie, P., Ruso, V, Lopez Galarza, S., Sakata, Y., 2008. A Review of production systems on watermelon quality. Roceedings of the IXth EUCARPIA Meeting on 98 Genetics and Breeding of Cucurbitaceae (M. PITRAT, editor), INRA, Avignon, France, 515-520.

Doorenbos, J., Kassam, A.H., 1979. Yield response to water. FAO Irrigation and Drainage Paper No. 33, Rome.

Enoch, H.Z., Enoch, Y., 1999. The history and geography of greenhouse. In Stanhil, G. and Enoch, H.Z. (eds). Greenhouse Ecosystems. Ecosystems of the World 20. Elsevier, Amsterdam, pp.1-15.

FAOSTAT, 2014. Food and Agriculture Organization Corporate Statistical Database. http://www.fao.org/faostat/en/\#data/QC

FAOSTAT, 2016. Food and Agriculture Organization Corporate Statistical Database. http://www.fao.org/faostat/en/\#data/QC

Hartz, T.K., 1993. Drip irrigation scheduling for fresh market tomato production. Hort. Science, 28: $35-37$.

Himanshu, S.K., Kumar, S., Kumar, D., Mokhtar, A., 2012. Effects of lateral spacing and irrigation scheduling on drip irrigated cabbage (Brassica oleracea) in a semiarid region of India. Research Journal of Engineering Sciences 1(5): 1-6.

Imtiyaz, M., Mgadla, N.P., Manase, S.K., Chendo, K., Mothobi, E.O., 2000. Yield and economic return of vegetable crops under variable irrigation. Irrigation Science 19(2): 87-93.

Janes, B.E., 1950. The effect of irrigation, nitrogen level and season on the composition of cabbage. Plant Physiology 25 (3): 441-452.

Jangandi, S., Shekar, B.G., Sridhara, S., 2000. Water use efficiency and yield of cabbage as influenced by drip and furrow methods of irrigation. Indian Agriculturist 44(3/4):153-155. 
Kiziloglu, F.M., Turan, M., Sahin, U., Angin, I., Anapali, O., Okuroglu, M., 2007. Effects of waste water irrigation on soil and cabbage plant chemical properties. J. Plant Nutr. Soil Sci. 170: 166-172. DOI: 10.1002/jpln.200621971.

Kiziloglu, F.M., Turan, M., Sahin U., Angin, I., Anapali, O., Okuroglu, M., 2007. Effects of waste water irrigation on soil and cabbage plant chemical properties. J. Plant Nutr. Soil Sci. 170: 166-172. DOI: 10.1002/jpln.200621971.

Kiziloglu, F.M., Turan, M., Sahin, U., Kuslu Y., Dursun A., 2008. Effects of untreated and treated wastewater irrigation on some chemical properties of cauliflower and red cabbage grown on calcareous in Turkey. Agricultural Water Management 95: 716-724. doi:10.1016/j.agwat.2008.01.008.

Kumar, P., Sahu, R.L., 2013. Effects of irrigation and fertigation levels on cabbage. An Asian Journal of Soil Science 8(2): 270-274.

Kushwah, S.S., Dwivedi, Y.C., 2013. Effect of different methods of irrigation and moisture regimes on yield and water economy in cabbage (Brassica oleracea L. var. capitata). Asian J. Hort 8(1): 43-45.

Nortje, P.F., Henrico, P.J., 1988. The effects of suboptimal irrigation and intra-row spacing on the yield and quality of cabbages. Acta Hort. 228(2):163-170.

McNeish, C.M., Welch, N.C., Nelson, R.D., 1985. Trickle irrigation requirements for stawberries in coastal California. J. Am. Soc. Hortic. Sci. 110: 714-718.

Ritchie, J.T., Johnson, B.S., 1990. Irrigation of agricultural crops. Agronomy Monograph, No 30: 363-390.

Salo, T., Suojala, T., Kallela, M., 2002. The effect of fertigation on yield and nutrient uptake of cabbage, carrot and onion. Acta Hort. 571:235-241. DOI: 10.17660/ActaHortic.2002.571.28.

Sammis, T.W., Kratky, B.A., Wu, I.P., 1988. Effects of limited irrigation on lettuce and Chinese cabbage yields. Irrig. Sci. (9): 187-198. https://doi.org/10.1007/BF00275431.

Sammis, T., Wu, I.P., 1989. Deficit irrigation effects on head cabbage production. Agricultural Water Management, Vol.16, Issue (3): 229-239. https://doi.org/10.1016/0378-3774(89)90005$\underline{X}$.

Seciu, A.M., Oancea, A., Gaspar, A., Moldovan, L., Craciunescu, O., Stefan, L., Petrus, V., Georgescu, F., 2016. Water use efficiency on cabbage and cauliflower treated with a new biostimulant composition. Agriculture and Agricultural Science Procedia 10: 475-484. https://doi.org/10.1016/j.aaspro.2016.09.019.

Sezen, S.M., 2005. Effects of drip irrigation management on yield and quality of field grown green beans. Agricultural Water Management 71(2005)243-255.

Steel, R.G.D., Torrie, J.H., 1980. Principles and procedures of statistics. A biometrical approach. McGraw-Hill, NewYork, pp.186-187. 
Stewart, J.I., Misra, R.D., Pruitt, W.O., Hagan, R.M., 1975. Irrigating corn and sorghum with a deficient water supply. Trans. ASAE, 18: 270-280.

Sturm, M., Marsic, N.K., Zupanc, V., Zeleznik, B.B., Lojen S, Pintar M. 2010. Effect of different fertilization and irrigation practices on yield, nitrogen uptake and fertilizer use efficiency of white cabbage (Brassica oleracea var. capitata L.). Scientia Horticulturae 125(2):103-109. DOI: 10.1016/j.scienta.2010.03.017.

Tiwari, K.N., Singh, A., Mal, P.K., 2003. Effect of drip irrigation on yield of cabbage (Braccica oleracea L. var. capitata) under mulch and non-mulch conditions. Agricultural Water Management (58): 19-28. https://doi.org/10.1016/S0378-3774(02)00084-7.

Von Elsner, B., Briassoulis, D., Waaijenberg, D., Mistriotis, A., Von Zabeltizt, C.H.R. and Gratraud, J., 2000. Mechanical properties of covering materials for greenhouses. Part I. General overview. J. Agric. Eng. Res., 67: 81- 96.

Vural, H., Eşiyok, D., Duman, İ., 2000. Cultivated vegetables (Kültür sebzeleri), Ege University press, 440 p. (In Turkish)

Wahome, P.K., Shongwe, V., Mbewe, D.N., 2009. Response of cabbage (Brassica oleraceae var. capitata) to mulching and different irrigation regimes. Am-Euras. J. Agric \&. Environ. Sci. 6(6): 662-669.

$\mathrm{Xu}, \mathrm{C}$., Leskovar, D.I., 2014. Growth, physiology and yield responses of cabbage to deficit irrigation. Hort. Sci., 41(3):138-146.

Yuan, B.Z., Sun, J., Nishiyama, S., 2003. Effect of drip irrigation on strawberry growth inside a plastic greenhouse. Biosystems Engineering, 87 (2): 237- 245. 
Table 1. Some of chemical and physical properties of experimental field soil

\begin{tabular}{ccccccccc}
\hline $\begin{array}{c}\text { Soil } \\
\text { Depth } \\
(\mathrm{cm})\end{array}$ & Soil Type & $\begin{array}{c}\text { Unit } \\
\text { weight } \\
(\mathrm{gr} / \mathrm{cm} 3)\end{array}$ & $\begin{array}{c}\text { Field } \\
\text { Capacity } \\
(\%)\end{array}$ & $\begin{array}{c}\text { Wilting } \\
\text { point } \\
(\%)\end{array}$ & $\mathrm{pH}$ & $\begin{array}{c}\text { Total salt } \\
(\%)\end{array}$ & $\begin{array}{c}\mathrm{CaCO}_{3} \\
(\%)\end{array}$ & $\begin{array}{c}\text { Organic } \\
\text { matter } \\
(\%)\end{array}$ \\
\hline $0-30$ & SL & 1.34 & 29.73 & 21.74 & 7.99 & 0.037 & 16.5 & 2.92 \\
$30-60$ & SL & 1.37 & 27.26 & 19.37 & 8.04 & 0.031 & 29.5 & 1.39 \\
$60-90$ & SL & 1.58 & 33.92 & 23.72 & 7.86 & 0.034 & 31.5 & 1.08 \\
$90-120$ & SL & 1.50 & 36.30 & 27.73 & 8.05 & 0.032 & 33.0 & 0.94 \\
\hline
\end{tabular}

Table 2. Experimental treatments

\begin{tabular}{|c|c|c|c|c|}
\hline \multirow{2}{*}{$\begin{array}{l}\text { Irrigation } \\
\text { treatments }\end{array}$} & \multicolumn{4}{|c|}{ Growth Stages } \\
\hline & Establishment & Vegetative & Yield Formation & Ripening \\
\hline 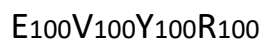 & + & + & + & + \\
\hline E75VYR & + \%25 su kısıntısı & + & + & + \\
\hline E50VYR & + \%50 su kısıntısı & + & + & + \\
\hline E25VYR & + \%75 su kısıntısı & + & + & + \\
\hline EV75YR & + & + \%25 su kısıntısı & + & + \\
\hline $\mathrm{EV}_{50 \mathrm{Y}}$ & + & + \%50 su kısıntısı & + & + \\
\hline$E V_{25} Y R$ & + & + \%75 su kısıntısı & + & + \\
\hline$E V Y_{75} R$ & + & + & + \%25 su kısıntısı & + \\
\hline $\mathrm{EVY}_{50 \mathrm{R}}$ & + & + & + \%50 su kısıntısı & + \\
\hline $\mathrm{EVY}_{25} \mathrm{R}$ & + & + & + \%75 su kısıntısı & + \\
\hline EVYR75 & + & + & + & + \%25 su kısıntısı \\
\hline EVYR50 & + & + & + & + \%50 su kısıntısı \\
\hline EVYR25 & + & + & + & + \%75 su kısıntısı \\
\hline EoVoYoRo & & - & - & - \\
\hline
\end{tabular}

+: Water application in the specified period, -: Without irrigation

Table 3. Chemical composition of irrigation water used in the experiment

\begin{tabular}{|c|c|c|c|c|c|c|c|c|}
\hline \multirow{2}{*}{$\begin{array}{l}\text { Water } \\
\text { Source }\end{array}$} & & $\mathrm{Na}^{+}$ & $\mathrm{K}^{+}$ & $\mathrm{Ca}^{2+}$ & $\mathrm{Mg}^{2+}$ & \multirow[b]{2}{*}{$\mathrm{PH}$} & \multirow[b]{2}{*}{ Class } & \multirow[b]{2}{*}{ SAR } \\
\hline & $\mathrm{EC}_{25} \mathrm{x}\left(10^{6}\right)$ & \multicolumn{4}{|c|}{$\left(\mathrm{me} \mathrm{L}^{-1}\right)$} & & & \\
\hline $\begin{array}{c}\text { Deep } \\
\text { well }\end{array}$ & 715 & 2.3 & 2.56 & 9.25 & 5.7 & 7.12 & $\mathrm{C}_{2} \mathrm{~S}_{1}$ & 0.85 \\
\hline
\end{tabular}


Table 4. The amount of irrigation water applied for the different growth stages according to the treatments

\begin{tabular}{|c|c|c|c|c|c|c|c|c|c|c|}
\hline \multicolumn{11}{|c|}{ Irrigation Water (mm) } \\
\hline \multirow{2}{*}{ Konular } & \multicolumn{2}{|c|}{ Establishment } & \multicolumn{2}{|c|}{ Vegetative } & \multicolumn{2}{|c|}{ Yield Formation } & \multicolumn{2}{|c|}{ Ripening } & \multicolumn{2}{|c|}{ Total } \\
\hline & 2007 & 2008 & 2007 & 2008 & 2007 & 2008 & 2007 & 2008 & 2007 & 2008 \\
\hline E100V100Y100R100 & 40 & 60 & 140 & 150 & 170 & 160 & 174 & 166 & 524 & 536 \\
\hline E75VYR & 30 & 45 & 140 & 150 & 170 & 160 & 174 & 166 & 514 & 521 \\
\hline E50VYR & 20 & 30 & 140 & 150 & 170 & 160 & 174 & 166 & 504 & 498 \\
\hline E25VYR & 10 & 15 & 140 & 150 & 170 & 160 & 174 & 166 & 494 & 487 \\
\hline EV75YR & 40 & 60 & 105 & 112 & 170 & 160 & 174 & 166 & 489 & 498 \\
\hline $\mathrm{EV}{ }_{50} \mathrm{YR}$ & 40 & 60 & 70 & 75 & 170 & 160 & 174 & 166 & 454 & 461 \\
\hline EV $25 \mathrm{YR}$ & 40 & 60 & 35 & 38 & 170 & 160 & 174 & 166 & 419 & 424 \\
\hline EVY75R & 40 & 60 & 140 & 150 & 128 & 120 & 174 & 166 & 482 & 496 \\
\hline EVY $Y_{50}$ & 40 & 60 & 140 & 150 & 85 & 80 & 174 & 166 & 439 & 456 \\
\hline $\mathrm{EVY}_{25 \mathrm{R}}$ & 40 & 60 & 140 & 150 & 43 & 40 & 174 & 166 & 397 & 416 \\
\hline EVYR75 & 40 & 60 & 140 & 150 & 170 & 160 & 130 & 124 & 480 & 494 \\
\hline EVYR50 & 40 & 60 & 140 & 150 & 170 & 160 & 87 & 83 & 437 & 453 \\
\hline EVYR25 & 40 & 60 & 140 & 150 & 170 & 160 & 44 & 42 & 394 & 412 \\
\hline EOVoYoRo & 0 & 0 & 0 & 0 & 0 & 0 & 0 & 0 & 0 & 0 \\
\hline
\end{tabular}

Table 5. Crop evapotranspiration for the different growth stages according to to the treatments

\begin{tabular}{|c|c|c|c|c|c|c|c|c|c|c|}
\hline \multicolumn{11}{|c|}{ Crop Evapotranspiration (mm) } \\
\hline \multirow{2}{*}{ Konular } & \multicolumn{2}{|c|}{ Establishment } & \multicolumn{2}{|c|}{ Vegetative } & \multicolumn{2}{|c|}{ Yield Formation } & \multicolumn{2}{|c|}{ Ripening } & \multicolumn{2}{|c|}{ Total } \\
\hline & 2007 & 2008 & 2007 & 2008 & 2007 & 2008 & 2007 & 2008 & 2007 & 2008 \\
\hline$E_{100} V_{100} Y_{100} R_{100}$ & 50 & 65 & 195 & 190 & 210 & 212 & 340 & 335 & 795 & 802 \\
\hline E75VYR & 50 & 65 & 194 & 187 & 202 & 210 & 333 & 335 & 779 & 797 \\
\hline E50VYR & 46 & 60 & 186 & 182 & 195 & 193 & 327 & 329 & 754 & 764 \\
\hline E25VYR & 43 & 56 & 183 & 178 & 191 & 186 & 320 & 316 & 737 & 736 \\
\hline$E V_{75} Y R$ & 53 & 67 & 165 & 175 & 204 & 207 & 323 & 307 & 745 & 756 \\
\hline EV 50 YR & 50 & 65 & 115 & 120 & 201 & 203 & 332 & 325 & 698 & 713 \\
\hline $\mathrm{EV}_{25} \mathrm{YR}$ & 52 & 62 & 60 & 62 & 197 & 197 & 330 & 330 & 639 & 651 \\
\hline EVY75R & 42 & 56 & 125 & 148 & 230 & 220 & 320 & 306 & 717 & 730 \\
\hline$E V Y_{50 R}$ & 40 & 53 & 171 & 180 & 155 & 145 & 335 & 335 & 701 & 713 \\
\hline$E V Y_{25} R$ & 40 & 53 & 174 & 182 & 78 & 73 & 331 & 332 & 623 & 640 \\
\hline EVYR75 & 43 & 52 & 132 & 138 & 165 & 160 & 325 & 302 & 665 & 652 \\
\hline EVYR50 & 40 & 50 & 130 & 150 & 194 & 192 & 250 & 185 & 614 & 577 \\
\hline EVYR25 & 40 & 50 & 138 & 183 & 207 & 202 & 145 & 132 & 530 & 567 \\
\hline EOVOYORO & 40 & 50 & 45 & 45 & 50 & 45 & 50 & 50 & 185 & 190 \\
\hline
\end{tabular}


Table 6. Relationship between the decrease in relative water use and decrease in relative yield and yield response factor for cabbage irrigated by a drip system in 2007 and 2008

\begin{tabular}{|c|c|c|c|c|c|c|c|c|c|}
\hline $\begin{array}{l}\text { Irrigation } \\
\text { Treatment }\end{array}$ & Vield $\left(\right.$ tha $\left.^{-1}\right)$ & $\begin{array}{c}\text { Applied } \\
\text { Water }(\mathrm{mm})\end{array}$ & $\mathrm{ETa}(\mathrm{mm})$ & $\mathrm{ETa} / \mathrm{ETm}$ & $\mathrm{Va} / \mathrm{Mm}$ & 1-(ETa/Etm) & 1-( $(\mathrm{Ya} / \mathrm{Ym})$ & ky & ky \\
\hline E100V $100 Y_{100 R}{ }_{100}$ & 74,2 & 524 & 795 & 1,000 & 1,000 & 0,000 & 0,000 & 0,000 & 0,000 \\
\hline E75VYYR & 73,8 & 514 & 779 & 0,980 & 0,995 & 0,020 & 0,005 & 0,268 & \multirow{3}{*}{0,470} \\
\hline E50VYR & 72,3 & 506 & 754 & 0,948 & 0,974 & 0,052 & 0,026 & 0,497 & \\
\hline E25VYYR & 70,7 & 494 & 737 & 0,927 & 0,953 & 0,073 & 0,047 & 0,647 & \\
\hline EV75YR & 68,4 & 489 & 745 & 0,937 & 0,922 & 0,063 & 0,078 & 1,243 & \multirow{3}{*}{0,844} \\
\hline EV 50 YR & 67,2 & 454 & 698 & 0,878 & 0,906 & 0,122 & 0,094 & 0,773 & \\
\hline $\mathrm{EV} 25 \mathrm{YR}$ & 66,7 & 419 & 639 & 0,804 & 0,899 & 0,196 & 0,101 & 0,515 & \\
\hline EVY75R & 63,5 & 482 & 717 & 0,902 & 0,856 & 0,098 & 0,144 & 1,470 & \multirow{3}{*}{1,226} \\
\hline EVY50R & 62,8 & 439 & 701 & 0,882 & 0,846 & 0,118 & 0,154 & 1,299 & \\
\hline $\mathrm{EVY} / 25 \mathrm{R}$ & 59,6 & 397 & 623 & 0,784 & 0,803 & 0,216 & 0,197 & 0,909 & \\
\hline EVYR75 & 54,8 & 480 & 665 & 0,836 & 0,739 & 0,164 & 0,261 & 1,599 & \multirow{3}{*}{1,281} \\
\hline EVYR50 & 52,4 & 437 & 614 & 0,772 & 0,706 & 0,228 & 0,294 & 1,290 & \\
\hline EVYR25 & 50,6 & 394 & 530 & 0,667 & 0,682 & 0,333 & 0,318 & 0,954 & \\
\hline EOVOYORO & 2,0 & 0 & 200 & 0,252 & 0,027 & 0,748 & 0,973 & 1,300 & 1,300 \\
\hline $\begin{array}{l}\text { Irrigation } \\
\text { Treatment }\end{array}$ & Vield $\left(\right.$ tha $\left.^{-1}\right)$ & $\begin{array}{c}\text { Applied } \\
\text { Water }(\mathrm{mm})\end{array}$ & $\mathrm{ETa}(\mathrm{mm})$ & $\mathrm{ETa} / \mathrm{ETm}$ & $\mathrm{Ya} / \mathrm{Ym}$ & 1-(ETa/Etm) & 1-( $(\mathrm{Ya} / \mathrm{Ym})$ & ky & ky \\
\hline E100V100Y100R100 & 72,4 & 536 & 802 & 1,000 & 1,000 & 0,000 & 0,000 & 0,000 & 0,000 \\
\hline E75VYR & 72,0 & 521 & 797 & 0,994 & 0,994 & 0,006 & 0,006 & 0,886 & \multirow[b]{3}{*}{0,488} \\
\hline E50VYR & 71,4 & 498 & 764 & 0,953 & 0,986 & 0,047 & 0,014 & 0,292 & \\
\hline E25VYR & 70,7 & 487 & 736 & 0,918 & 0,977 & 0,082 & 0,023 & 0,285 & \\
\hline EV75YR & 67,9 & 498 & 756 & 0,943 & 0,938 & 0,057 & 0,062 & 1,084 & \multirow[b]{3}{*}{0,876} \\
\hline EV ${ }_{50} \mathrm{YR}$ & 67,6 & 461 & 713 & 0,889 & 0,934 & 0,111 & 0,066 & 0,597 & \\
\hline $\mathrm{EV}_{25} \mathrm{YR}$ & 59,5 & 424 & 651 & 0,812 & 0,822 & 0,188 & 0,178 & 0,946 & \\
\hline EVY75R & 63,9 & 496 & 730 & 0,910 & 0,883 & 0,090 & 0,117 & 1,308 & \multirow[b]{3}{*}{1,252} \\
\hline EVY50R & 60,7 & 456 & 713 & 0,889 & 0,838 & 0,111 & 0,162 & 1,456 & \\
\hline $\mathrm{EVY} / 25 \mathrm{R}$ & 57,9 & 416 & 640 & 0,798 & 0,800 & 0,202 & 0,200 & 0,991 & \\
\hline EVYR75 & 57,6 & 494 & 652 & 0,813 & 0,796 & 0,187 & 0,204 & 1,093 & \multirow[b]{3}{*}{1,260} \\
\hline EVYR50 & 52,1 & 453 & 577 & 0,813 & 0,720 & 0,187 & 0,280 & 1,499 & \\
\hline EVYR25 & 50,4 & 412 & 597 & 0,744 & 0,696 & 0,256 & 0,304 & 1,189 & \\
\hline EOVOYORO & 4,0 & 0 & 190 & 0,237 & 0,055 & 0,763 & 0,945 & 1,238 & 1,238 \\
\hline
\end{tabular}


Table 7. Crop water production functions obtained for each growth stage and total growing season in 2007 and 2008

\begin{tabular}{|c|c|c|}
\hline Year & Period & Production Functions \\
\hline \multirow{5}{*}{2007} & $\mathrm{E}$ & $(1-Y a / Y m)=0.47$ (1-Eta/Etm), $R^{2}=0.9837$ \\
\hline & V & $(1-Y a / Y m)=0.84(1-E t a / E t m), R 2=0.9134$ \\
\hline & $\mathrm{Y}$ & $(1-\mathrm{Ya} / \mathrm{Ym})=1.23(1-\mathrm{Eta} / \mathrm{Etm}), \mathrm{R} 2=0.9999$ \\
\hline & $\mathrm{R}$ & $(1-Y a / Y m)=1.28(1-E t a / E t m), R 2=0.9513$ \\
\hline & Seasonal & $(1-\mathrm{Ya} / \mathrm{Ym})=0.96(1-\mathrm{Eta} / \mathrm{Etm}), \mathrm{R} 2=0.9530$ \\
\hline \multirow{5}{*}{2008} & $\mathrm{E}$ & $(1-Y a / Y m)=0.49(1-E t a / E t m), R 2=0.9916$ \\
\hline & V & $(1-Y a / Y m)=0.88(1-E t a / E t m), R 2=0.8568$ \\
\hline & $\mathrm{Y}$ & $(1-Y a / Y m)=1.25(1-E t a / E t m), R 2=0.8601$ \\
\hline & $\mathrm{R}$ & $(1-Y a / Y m)=1.26(1-E t a / E t m), R 2=0.7800$ \\
\hline & Seasonal & $(1-\mathrm{Ya} / \mathrm{Ym})=0.97(1-\mathrm{Eta} / \mathrm{Etm}), \mathrm{R} 2=0.9814$ \\
\hline
\end{tabular}

Table 8. Effects of irrigation treatments on cabbage parameters in 2007

\begin{tabular}{|c|c|c|c|c|c|}
\hline \multicolumn{6}{|c|}{2007} \\
\hline $\begin{array}{l}\text { Irrigation } \\
\text { Treatment }\end{array}$ & Yield $\left(\mathrm{t} \mathrm{ha}^{-1}\right)$ & $\begin{array}{l}\text { Head Weight } \\
(\mathrm{kg})\end{array}$ & $\begin{array}{c}\text { Head } \\
\text { Diameter }(\mathrm{cm})\end{array}$ & $\begin{array}{l}\text { Head Height } \\
(\mathrm{cm})\end{array}$ & Dry Matter (\%) \\
\hline 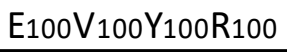 & $74.2 \mathrm{a}$ & $5.8 \mathrm{a}$ & $30.2 \mathrm{a}$ & $28.8 \mathrm{a}$ & $7.2 \mathrm{j}$ \\
\hline E75VYR & $73.8 \mathrm{a}$ & $5.7 a b$ & $30.0 \mathrm{a}$ & $28.4 \mathrm{ab}$ & $7.2 \mathrm{j}$ \\
\hline E50VYR & $72,3 \mathrm{~b}$ & $5.6 \mathrm{ab}$ & $28.2 \mathrm{ab}$ & $27.5 b c$ & $7.5 \mathrm{ij}$ \\
\hline E25VYR & $70.7 c$ & $5.5 \mathrm{abc}$ & $27.5 b$ & $26.4 c$ & $7.8 \mathrm{hl}$ \\
\hline EV75YR & $68.4 \mathrm{~d}$ & $5.3 \mathrm{abcd}$ & $27.3 b$ & $26.2 c$ & 7.7 hij \\
\hline $\mathrm{EV}_{50} \mathrm{YR}$ & $66.2 \mathrm{e}$ & 5.1 bcde & $24.5 c$ & $24.7 \mathrm{de}$ & $8.0 \mathrm{ghı}$ \\
\hline $\mathrm{EV}_{25} \mathrm{YR}$ & $67.7 \mathrm{e}$ & $4.9 \mathrm{cde}$ & $22.4 \mathrm{~cd}$ & 23.7 efg & $8.7 \mathrm{def}$ \\
\hline EVY75R & $63.5 \mathrm{f}$ & $4.9 \mathrm{cde}$ & $24.0 c$ & $25.4 \mathrm{~d}$ & $8.2 \mathrm{fgh}$ \\
\hline $\mathrm{EVY}_{50 \mathrm{R}}$ & $62.8 \mathrm{f}$ & $4.5 \mathrm{de}$ & $21.8 \mathrm{de}$ & $22.5 \mathrm{fg}$ & $8.8 \mathrm{de}$ \\
\hline$E V Y_{25} R$ & $59.6 \mathrm{~g}$ & $4.0 \mathrm{ef}$ & $18.0 \mathrm{f}$ & $20.1 \mathrm{hl}$ & $9.6 \mathrm{bc}$ \\
\hline EVYR75 & $54.8 \mathrm{~h}$ & $4.8 \mathrm{ef}$ & $22.8 \mathrm{~cd}$ & $24.5 \mathrm{def}$ & $8.5 \mathrm{efg}$ \\
\hline EVYR50 & 52.41 & $4.5 \mathrm{f}$ & $20.1 \mathrm{ef}$ & $21.3 \mathrm{gh}$ & $9.2 \mathrm{~cd}$ \\
\hline EVYR25 & $50.6 j$ & $3.9 \mathrm{f}$ & $15.2 \mathrm{~g}$ & 18.7 I & $10.1 \mathrm{~b}$ \\
\hline EoVoYoRo & $2.0 \mathrm{k}$ & $0.5 \mathrm{~g}$ & $6.0 \mathrm{~h}$ & $6.7 \mathrm{j}$ & $13.5 \mathrm{a}$ \\
\hline Treatments & $*$ & $*$ & $*$ & $*$ & * \\
\hline Blocks & is & is & is & is & is \\
\hline
\end{tabular}

** means correlation is significant at the 0.005 level. ns shows non-significant correlation. 
Table 9. Effects of irrigation treatments on cabbage parameters in 2008

\begin{tabular}{|c|c|c|c|c|c|}
\hline \multicolumn{6}{|c|}{2008} \\
\hline $\begin{array}{l}\text { Irrigation } \\
\text { Treatment }\end{array}$ & Yield $\left(\mathrm{t} \mathrm{ha}^{-1}\right)$ & $\begin{array}{c}\text { Head Weight } \\
(\mathrm{kg})\end{array}$ & $\begin{array}{c}\text { Head } \\
\text { Diameter }(\mathrm{cm})\end{array}$ & Head Height $(\mathrm{cm})$ & Dry Matter (\%) \\
\hline $\mathrm{E}_{100} \mathrm{~V}_{100} \mathrm{Y}_{100 \mathrm{R}_{100}}$ & $72.4 \mathrm{a}$ & $5.6 \mathrm{a}$ & $30.3 \mathrm{a}$ & $28.8 \mathrm{a}$ & $7.0 \mathrm{~g}$ \\
\hline E75VYR & $72.0 \mathrm{a}$ & $5.6 \mathrm{a}$ & $30.2 \mathrm{a}$ & $28.4 \mathrm{ab}$ & $7.1 \mathrm{~g}$ \\
\hline E50VYR & $71.4 \mathrm{a}$ & $5.5 \mathrm{a}$ & $28.4 \mathrm{ab}$ & $27.5 b$ & $7.4 \mathrm{fg}$ \\
\hline E25VYR & $70.7 \mathrm{a}$ & $5.4 \mathrm{a}$ & $27.2 \mathrm{bc}$ & $26.4 \mathrm{c}$ & $7.7 \mathrm{efg}$ \\
\hline EV75YR & $67.9 \mathrm{~b}$ & $5.4 \mathrm{a}$ & $27.4 \mathrm{bc}$ & $26.2 \mathrm{~cd}$ & $7.6 \mathrm{efg}$ \\
\hline $\mathrm{EV}_{50} \mathrm{YR}$ & $67.6 \mathrm{~b}$ & $5.2 a b$ & $25.9 \mathrm{~cd}$ & $24.7 \mathrm{e}$ & 8.0 efg \\
\hline $\mathrm{EV}_{25} \mathrm{YR}$ & $59.5 \mathrm{de}$ & $4.9 \mathrm{abc}$ & $24.2 \mathrm{de}$ & $23.7 f$ & 8.5 cde \\
\hline EVY75R & $63.9 c$ & $5.0 \mathrm{abc}$ & $25.0 \mathrm{~d}$ & $25.4 \mathrm{de}$ & 7.9 efg \\
\hline $\mathrm{EVY}_{50 \mathrm{R}}$ & $60.7 d$ & $4.5 \mathrm{bcd}$ & $22.6 \mathrm{ef}$ & $22.5 \mathrm{~g}$ & $8.6 \mathrm{cde}$ \\
\hline$E V Y_{25} R$ & $57.9 \mathrm{e}$ & $4.0 \mathrm{~d}$ & $20.2 \mathrm{~g}$ & 20.01 & $9.4 \mathrm{bc}$ \\
\hline EVYR75 & $57.6 \mathrm{e}$ & $5.0 \mathrm{abc}$ & $24.6 \mathrm{de}$ & $24.5 \mathrm{ef}$ & $8.2 \mathrm{def}$ \\
\hline EVYR50 & $52.1 \mathrm{f}$ & $4.4 \mathrm{~cd}$ & $21.4 \mathrm{fg}$ & $21.3 \mathrm{~h}$ & $9.1 \mathrm{~cd}$ \\
\hline EVYR25 & $50.4 \mathrm{f}$ & $3.8 \mathrm{~d}$ & $17.7 \mathrm{~h}$ & $18.7 \mathrm{j}$ & $10.3 \mathrm{~b}$ \\
\hline EoVoYoRo & $4.0 \mathrm{~g}$ & $0.4 \mathrm{e}$ & 6.51 & $6.7 \mathrm{k}$ & $13.7 \mathrm{a}$ \\
\hline Treatments & $*$ & $*$ & $*$ & $*$ & $*$ \\
\hline Blocks & is & is & is & is & is \\
\hline
\end{tabular}

** means correlation is significant at the 0.005 level. ns shows non-significant correlation.

Table 10. Total water use efficiency (WUE) and irrigation water use efficiency (IWUE) values for the cabbage irrigated by a drip system at different irrigation treatments.

\begin{tabular}{|c|c|c|c|c|c|c|c|}
\hline \multicolumn{4}{|c|}{2007} & \multicolumn{4}{|c|}{2008} \\
\hline $\begin{array}{l}\text { Irrigation } \\
\text { Treatment } \\
\end{array}$ & Yield $\left(\right.$ tha $\left.^{-1}\right)$ & WUE $\left(\mathrm{kg} / \mathrm{m}^{3}\right)$ & IWUE $\left(\mathrm{kg} / \mathrm{m}^{3}\right)$ & $\begin{array}{l}\text { Irrigation } \\
\text { Treatment } \\
\end{array}$ & Yield $\left(\mathrm{th}^{-1} \mathrm{-}^{-}\right.$ & WUE $\left(\mathrm{kg} / \mathrm{m}^{3}\right)$ & IWUE $\left(\mathrm{kg} / \mathrm{m}^{3}\right)$ \\
\hline $\mathrm{E}_{100} \mathrm{~V}_{100} \mathrm{Y}_{100} \mathrm{R}_{100}$ & 74,2 & 0,09 & 0,14 & $\Xi 100 \mathrm{~V}_{100} \mathrm{Y}_{100 \mathrm{R} 10 \mathrm{C}}$ & 72,4 & 0,09 & 0,14 \\
\hline E75VYR & 73,8 & 0,09 & 0,14 & E75VYR & 72,0 & 0,09 & 0,14 \\
\hline E50VYR & 72,3 & 0,10 & 0,14 & E50VYR & 71,4 & 0,09 & 0,14 \\
\hline E25VYR & 70,7 & 0,10 & 0,14 & E25VYR & 70,7 & 0,10 & 0,15 \\
\hline$E V_{75} Y_{R}$ & 68,4 & 0,09 & 0,14 & $E V_{75} Y_{R}$ & 67,9 & 0,09 & 0,14 \\
\hline $\mathrm{EV}_{50} \mathrm{YR}$ & 67,2 & 0,10 & 0,15 & EV50YR & 67,6 & 0,09 & 0,15 \\
\hline $\mathrm{EV}_{25} \mathrm{YR}$ & 66,7 & 0,10 & 0,16 & $\mathrm{EV}_{25} \mathrm{YR}$ & 59,5 & 0,09 & 0,14 \\
\hline$E V Y_{75 R}$ & 63,5 & 0,09 & 0,13 & $E V Y_{75 R}$ & 63,9 & 0,09 & 0,13 \\
\hline$E V Y_{50 R}$ & 62,8 & 0,09 & 0,14 & $E V Y_{50 R}$ & 60,7 & 0,09 & 0,13 \\
\hline$E V Y_{25} R$ & 59,6 & 0,10 & 0,15 & $E V Y_{25 R}$ & 57,9 & 0,09 & 0,14 \\
\hline EVYR75 & 54,8 & 0,08 & 0,11 & EVYR75 & 57,6 & 0,09 & 0,12 \\
\hline EVYR50 & 52,4 & 0,09 & 0,12 & EVYR50 & 52,1 & 0,09 & 0,12 \\
\hline$E V_{2} 25$ & 50,6 & 0,10 & 0,13 & EVYR25 & 50,4 & 0,08 & 0,12 \\
\hline EOVOYORO & 2,00 & 0,01 & 0,00 & EOVoYoRo & 4,0 & 0,02 & 0,00 \\
\hline
\end{tabular}




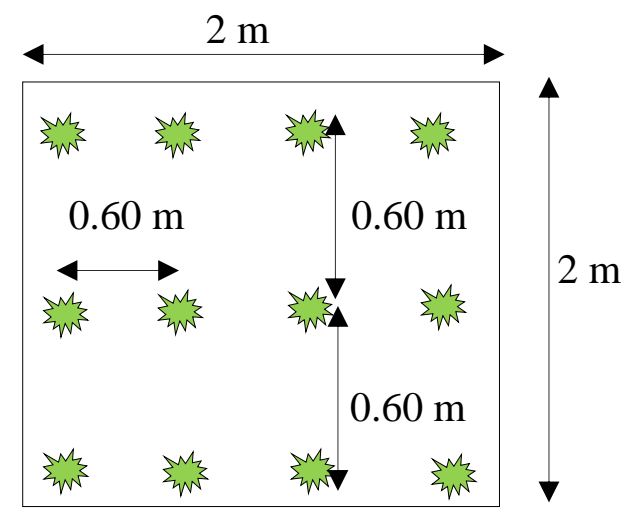

Figure 1. The detail of a plot

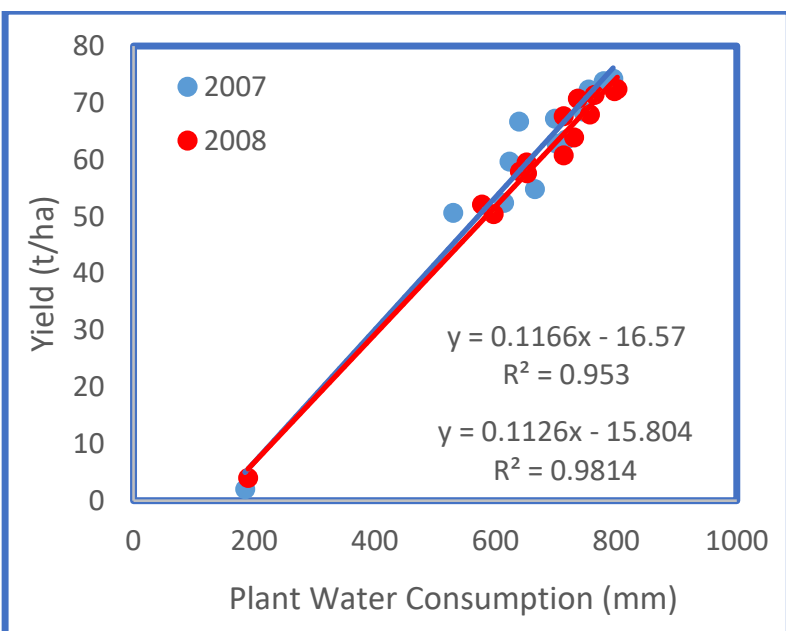

Figure 2. The relationship between Crop Water Consumption and Yield

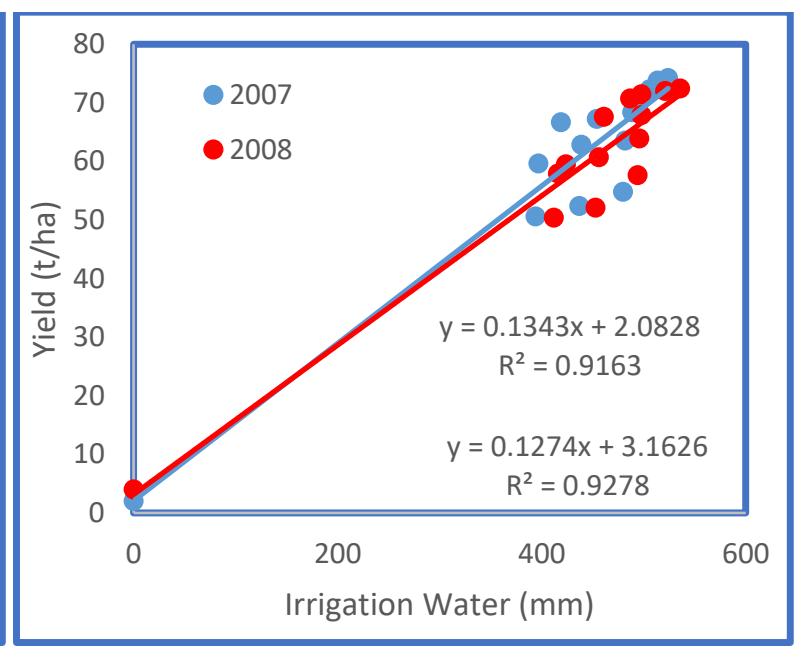

Figure 3. The relationship between Irrigation Water and Yield

Figure 4. Relationship between applied of irrigation water and head weight, head diameter, head height and dry matter ratio.
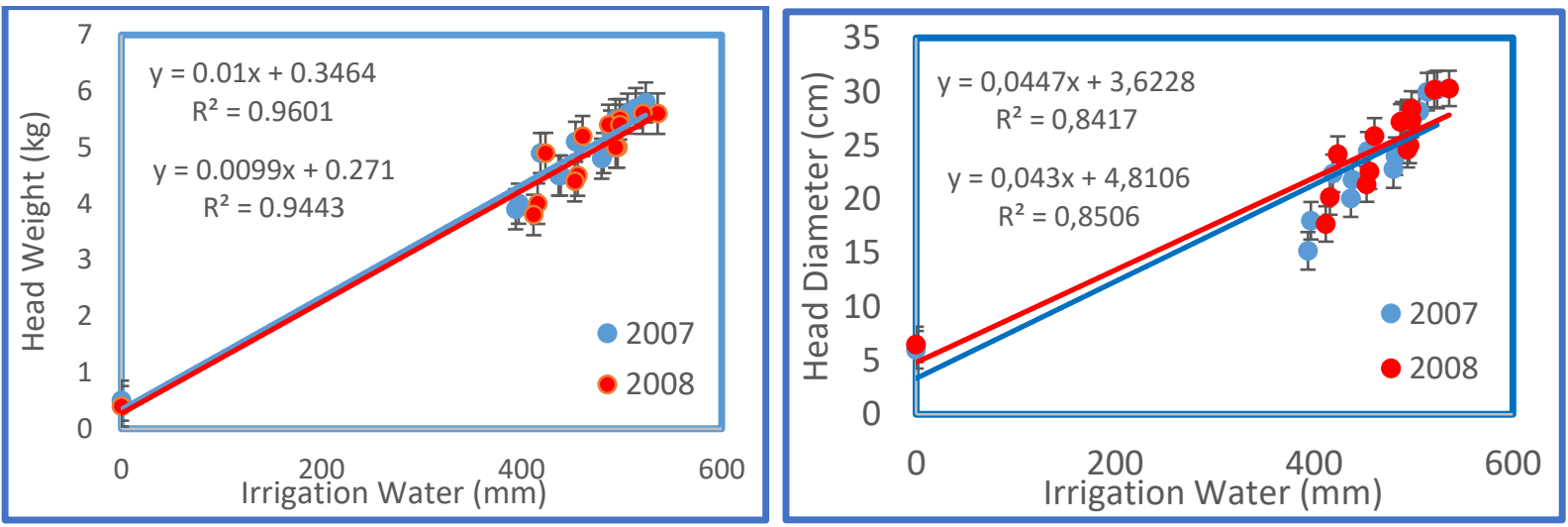

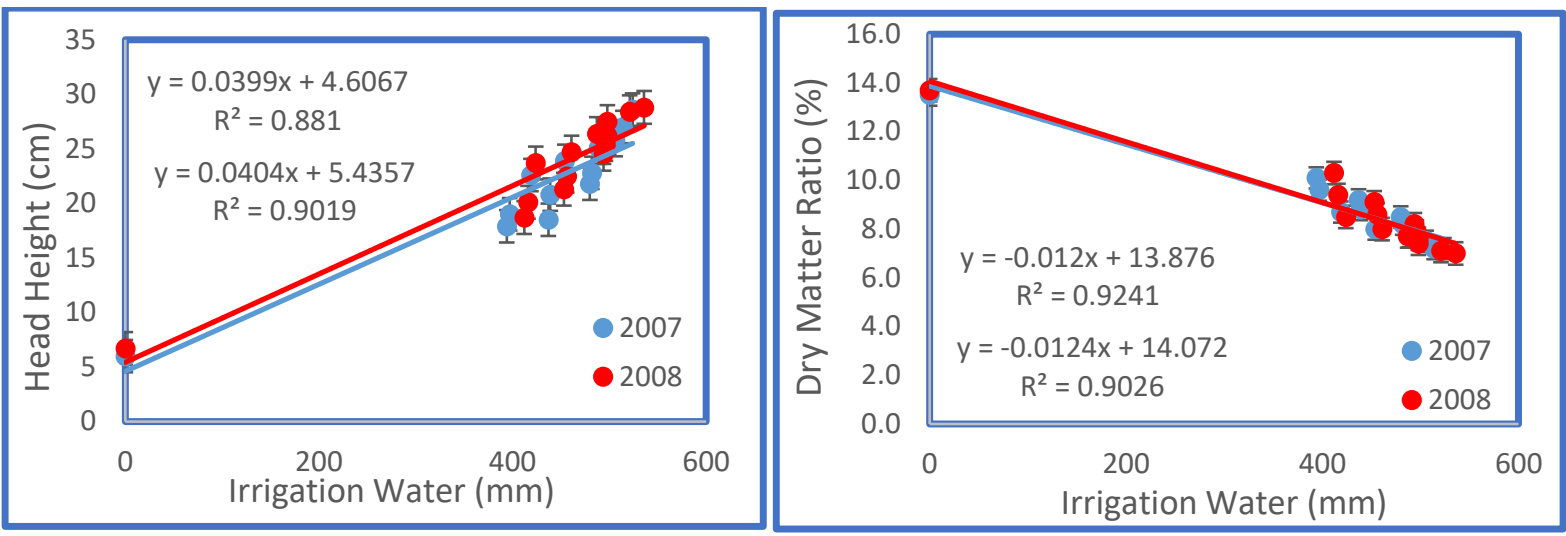

Figure 5. The relationship between relative yield decrease and relative evapotranspiration deficit for the experimental years (2007 and 2008)

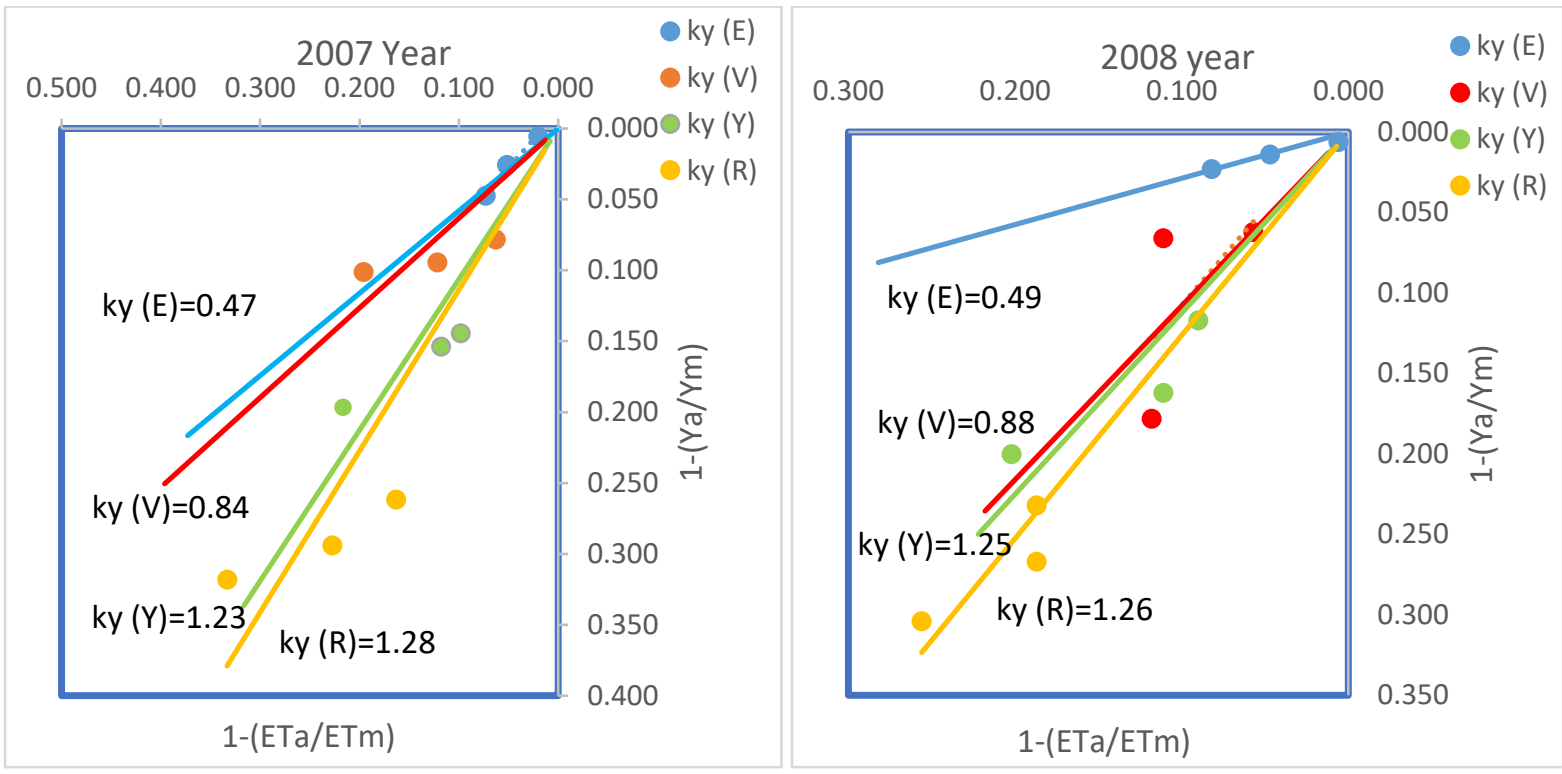

